\title{
A Study on a mechanical continuously variable injection timing system for improvement of agricultural small diesel DI engine
}

- Huynh Thanh Cong

Key-lab for Internal Combustion Engine, VNU-HCM - $\underline{\text { htcong@hcmut.edu.vn }}$

(Manuscript Received on October 11 ${ }^{\text {th }}$, 2012; Manuscript Revised December 30 ${ }^{\text {th }}$, 2012)

\section{ABSTRACT:}

This paper presents the development of a MCVIT (mechanical continuous variable injection timing) system for evaluating effects of injection timing - one of the efficiently experimental methods for improving diesel engine performance and emission characteristics to match modern emission regulations and bio-fuels. A MCVIT system has been designed and built with the ability to adjust freely and directly the injection timing for a wide range from 0 to $40^{\circ} \mathrm{CA} B T D C$ (before top dead center) while keeping the same injection pressure rate. Some experiments have been done to verify its significant specifications such as friction torque speed curve, accuracy and stability. The results show that the maximum friction torque of this system is around $2.6 \mathrm{~N} . \mathrm{m}$ over range of engine speed and its maximum deviation is $\pm 1.0^{\circ} \mathrm{CA}$ over a large range of testing injection timing. Preliminary study on VIKYNO RV215-2 agricultural small diesel DI engine has also proved that the engine performance and emission characteristics are directly influenced by injection timing. Thus the developed MCVIT system is an efficient and low cost tool for R\&D activities in small diesel engines.

Keywords: Diesel DI engine, injection timing, engine performance, emission characteristics.

\section{INTRODUCTION}

VIKYNO RV125-2 engine - water cooled 12.5HP single cylinder diesel DI engine - is the most popular agricultural small diesel DI engines for Vietnamese rural applications such as electricity generation, stationary power-trains and agricultural vehicles. Under very old designed license of $\operatorname{Kubota}^{\circledR}$, the engine performance characteristics were unsatisfied. Thus, its performances should be enhanced to fulfill the emission regulations for non-road engines such as US TIER 2 or STAGE II adopted by many target markets. Preliminary, the basic performance characteristics of that engine were reported and analyzed [1]. It was found that its exhaust emission is unsatisfied for TIER2 standard. Many measures [2-6] were studied to improve the performance characteristics of small diesel DI engines such as combustion chamber geometry modification, intake and exhaust 
system re-design, increase of injection pressure, and utilization of split injection systems. In this paper, the effects of injection timing's change on the engine performances are proposed to study.

Unlike distributor-injection pump and electrically controlled injectors, the injection timing of agricultural small diesel DI engine is unable to change freely. This fact demands to develop an injection control system that allows changing continuously the injection timing in a wide range. Also the system must has the same injection pressure rate, fast response, continuously tuning capability, low friction torque, high accuracy and stable operation. Such kind of system is not commercially available. In this study, a MCVIT system combined with an electronic injection timing checking system is successfully developed. The measure of injection timing's change has the benefits of time-saving, low-cost and suitable for agriculturally purposed engines. It is expected that the optimized injection timing could be better for both engine performance and emission characteristics.

Thus, this paper aims to demonstrate the MCVIT system and its characteristics and to evaluate the basic performance characteristics of the test engine with and without MCVIT system. Preliminary the effects of injection timing on performance and emission characteristics RV125-2 engine are also analyzed.

\section{DESIGN OF MCVIT SYSTEM}

A full MCVIT system consists of a cam phaser to adjust injection timing, an extra fuel delivery system and an electronic injection timing checking system.

\section{Principle of MCVIT system}

The MCVIT design concept is based on continuously variable cam phasing method. The original fuel delivery system is shut off and fuel is supplied to injector by an external fuel delivery system which uses a set of the same kind of camshaft, diesel-injection pump and high pressure line. Actually, original diesel-injection pump and high pressure line will be re-used as extra parts to keep exactly the same injection pressure rate and fuel delivery quantity.

As illustrated in Fig. 1, the extra dieselinjection pump is driven by the extra camshaft which is driven directly by timing gear of a pseudo crankshaft driven from engine flywheel via a cam phaser Fig. 3. The cam phaser consists of a timing belt, a pair of vertically movable pulleys and 04 fixed pulleys as belt guiders. The movable pulleys are a pair of 28-tooth gears that move in opposite directions. The displacement of movable pulleys $(\Delta \mathrm{x})$ produces relative angular between engine crankshaft and the pseudo crankshaft $(\Delta \theta)$ resulting in an injection timing change of the same value, i.e. $\Delta \theta$ ( ). The upward and downward displacements of movable pulleys results in advanced injection timing and retarded injection timing respectively.

There are some advantages of this design concept: (1) Injection timing, depending on presettings of the system and the displacement of movable pulleys can be varied in a wide range and fine tuning; (2) Injection timing can be changed directly with fast response during engine operation; (3) Easy to build and no requirement of highly precise machining methods. 

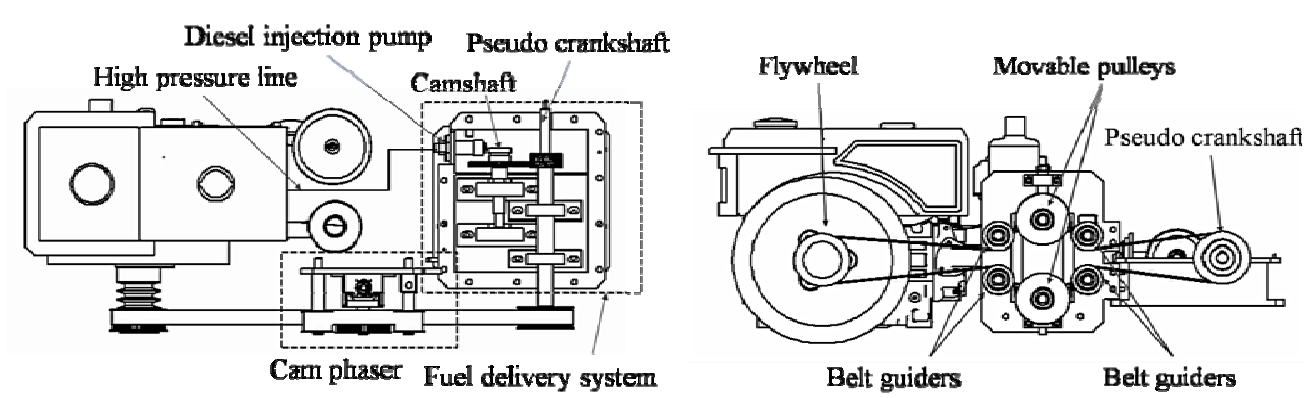

Fig. 1 Principle of MCVIT system

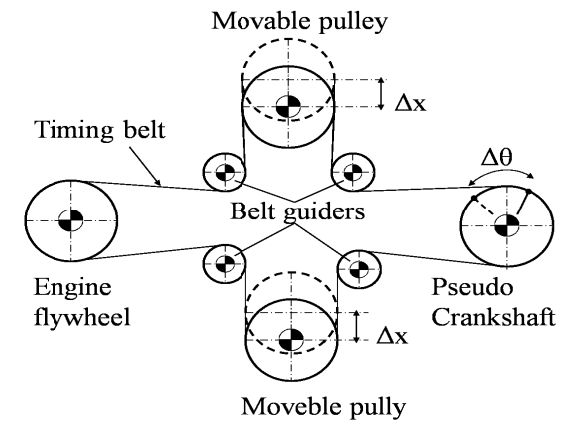

Fig. $2 \Delta \theta-\Delta x$ characteristics curve

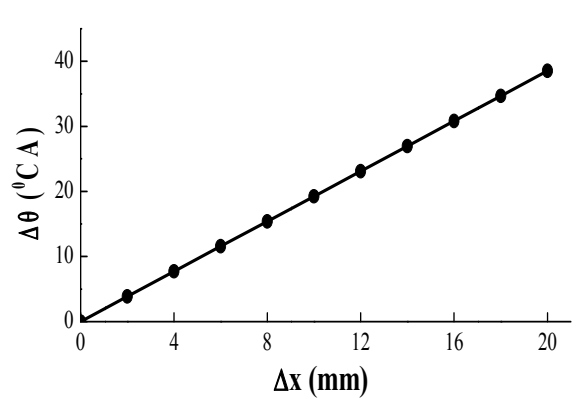

Fig. 3 Principle of cam phaser

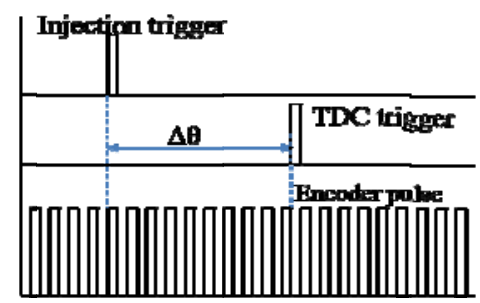

Fig. 4 Illustration of injection timing checking

There are also some disadvantages of this design concept: (1) friction loss is a part of total brake torque and should be taken into account; (2) the original centrifugal governor is removed and it is quite difficult to keep the engine running at a constant speed. Engine speed/torque control problem should be considered; (3) No autotensioner is used to avoid large deviation in injection timing. Thus, elasticity of timing belt can cause injection timing drift corresponding to the increase in engine speed and belt strain as well.

\section{Principle of electronic injection timing checking system}

The two last disadvantages require a real time injection timing checking that helps to check actual injection timing and compensate drifting. These help operator to supervise and adjust injection timing freely and quickly Fig. 4 and Fig. 5. The system consists of 


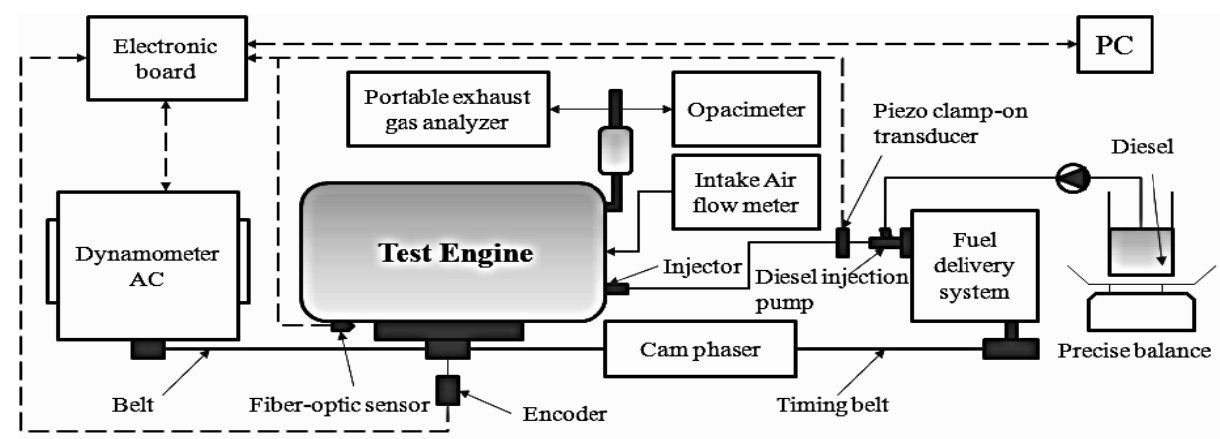

Fig. 5 Schematic diagram of experimental system

- Three sensors that provide input signals for injection timing determination: (1) a piezo clamp-on transducer used for detecting injection signal from the high pressure pipe in every engine cycle; (2) a position sensor used for capturing TDC mark on engine flywheel in every revolution; (3) an incremental encoder for continuously counting geometric CA.

- A micro-processor based electronic board for evaluation and display that uses the signal from piezo clamp-on transducer to reset a high speed counter and then starts to count number of encoder pulses until TDC position sensor sends a trigger signal to stop counting. Injection timing is determined from the counted pulses and pre-settings of the MCVIT system. In addition, this board will be used as an engine speed controller and data acquisition system in a full test system.

The accuracy of the system is mostly depended on sensitivity of piezo clamp-on transducer, deviation between captured TDC mark and real geometric TDC, and resolution of incremental encoder.

\section{EXPERIMENTAL SETUP}

To evaluate the performance characteristics of engine with and without MCVIT system, the engine and MCVIT system are set up the test bench and the experimental setup is shown in Fig. 5 consists of: VIKYNO RV125-2 diesel DI engine (with compression ratio of $18: 1$, bore and stroke are $94 \mathrm{~mm}$ x $90 \mathrm{~mm}$, displacement of ); engine dynamometer which includes an $\mathrm{AC}$ generator to convert engine output energy to electricity, air-cooled electric resistors to consume electricity, and a continuously variable exciter to vary brake load by adjusting exciting current; MCVIT system; micro-processor unit based electronic board for engine speed control, injection timing measurement and data acquisition including dynamometer brake torque, engine speed and injection timing; SARTORIUS TE6101 precise balance for fuel mass flow rate measurement; HESBON HG-520 portable exhaust gas analyzer for NOx analyzing; AVL DiSmoke 4000 for opacity measurement; FERRET INSTRUMENTS V765-01 piezo clamp-on transducer for diesel injection detection; AUTONICS FD-620-10 fiber optic sensor for TDC mark detection; AUTONICS E50S8-360-3-T-24 incremental encoder for counting geometric crank angle; and PC for realtime supervision, control and data acquisition. Dynamometer brake torque is measured via a

\section{Trang 60}


level arm and a load cell. Torque calibration is done before any tests.

There are 03 experiments which have been done to evaluate actual specifications and functions of the developed MCVIT system.

Test 1: Friction loss determination and fuel delivery check

The engine runs at $50 \%$ of load with constant speeds being set up on the range from 1,200 to $2,400 \mathrm{rpm}$ by a step of $200 \mathrm{rpm}$. Three test cases will be done, including: (1) disconnect the MCVIT system from the engine and use engine original fuel delivery system; (2) connects the MCVIT system to the engine but use engine original fuel delivery system; and (3) shut off engine original fuel delivery system and use the MCVIT system with full functions. The same injection timings are set up in the case $1 \& 2$.

The results of case 1 and 2 are used to determine the friction torque of MCVIT system which is a part of engine brake torque. It should be noted that engine brake torque (hereafter shortly called brake torque) is equal to dynamometer brake torque (hereafter shortly called measured brake torque) plus the friction torque of MCVIT system. The results of case 2 and 3 are used to evaluate the machining and assembly errors of MCVIT system effects on the injection pressure rate and fuel delivery quantity.

\section{Test 2: Accuracy and stability check}

Engine runs at $50 \%$ of load and 1,800rpm with injection timings being set up from TDC to $30^{\circ} \mathrm{CA}$ BTDC. The real-time injection timing is recorded to evaluate the accuracy and stability of MCVIT system.

Test 3: Preliminary study on the effect of injection timing on engine performance and emission characteristics at constant load and engine speed

The engine runs at $50 \%$ of load and 1,800 rpm with injection timings being set up at 4,8 , $10,12,14,16,20$ and $24^{\circ} \mathrm{CA}$ BTDC. Brake torque, brake power, brake thermal efficiency (BTE), brake specific fuel consumption (BSFC), NOx and opacity are measured and analyzed in accordance with change of injection timing.

\section{RESULT AND DISCUSSION}

Test result 1: Friction loss determination and fuel delivery check

As shown in Fig. 6, operating at the same fuel delivery quantities and injection timing, engine performances for case 2 and 3 are found to be similar over the whole engine speed range. Maximum deviations of measured brake torque and power are around $0.4 \mathrm{~N} . \mathrm{m}$ and $86 \mathrm{~W}$ respectively. These results show that MCVIT system could be able to keep the original injection pressure rate and fuel delivery quantity. This is a very important factor to ensure the same engine performance and emission characteristics with and without MCVIT system.

The deviation of measured brake torque between case 1 and 2 is used to determine the curve of friction torque and speed of a MCVIT system with an operating range (Fig. 7). Due to short speed range, this curve can be approximated by a linear equation as shown in Eq. 1.

$\mathrm{FT}=\left[\begin{array}{ll}0.0004 & 0.84107\end{array}\right][$ ne 1 $] \mathrm{T}$

When: $\quad$ FT [N.m]: friction torque

$$
\text { ne }[\mathrm{rpm}] \text { : engine speed }
$$

Eq. 1 will be used to correct measured brake torque and power to actual engine brake torque and power which are required for calculating 
brake specific fuel consumption and brake thermal efficiency.

As shown in the figure, additionally, the friction loss that was caused by the MCVIT system, is estimated over engine torque in percentage (\%). It is found that the relative friction loss is less than $7 \%$ for whole range of engine speed. This confirmed that the MCVIT system has a small effect on the brake torque.

\section{Test result 2: Accuracy and stability check}

Fig.8 illustrates accuracy and stability of injection timing over a wide range up to $40^{\circ} \mathrm{CA}$ BTDC. For each specific injection timing, maximum deviation is found to be around $\pm 1.0^{\circ} \mathrm{CA}$. This may be caused by the vibration in single cylinder diesel engine and the elasticity of timing belt. Especially, highly advanced injection timing causes too much engine vibration and can lead to high noise injection timing detection. Fast response and fine tuning ability are also illustrated in Fig 8.

\section{Test result 3: Preliminary study on effect of injection timings}

The effects of injection timing on engine performance characteristics are analyzed and shown in Fig. 9 \& Fig. 10. When injection timing is advanced from 4 to $24^{\circ} \mathrm{CA}$ BTDC, brake torque, brake power and BTE show the same trends and all reach their peak value at around 120CA BTDC. Respectively, BSFC obtains the lowest value at the same injection timing. In addition, NOx emission increases rapidly from about 500ppm to above $2,800 \mathrm{ppm}$. In contrast, opacity decreases drastically from above $7 \%$ to below $1 \%$. The above-mentioned results show that at $1800 \mathrm{rpm}$ injection timing from 8 to $14^{\circ} \mathrm{CA}$ are good for engine performance due to perfect match of, mixture preparation, combustion rate and thermodynamic processes in the combustion chamber. In case that more advance in injection timings (above $14^{\circ} \mathrm{CA}$ BTDC) will ignite the combustion sooner. This causes rapidly increasing of temperature and pressure in the combustion chamber, especially when the piston is moving toward combustion TDC. As the result of this, combustion energy loss increases; and brake torque, brake power, brake thermal efficiency and BFSC are all reduced. Higher combustion temperature and pressure are also good conditions to produce NOx. In contrast, opacity is reduced because fuel is burned easily and there is enough time for complete combustion. More retarded injection timings (below $8^{\circ} \mathrm{CA}$ BTDC) could lead to later starting point of combustion. Combustion process takes place mostly when the piston is running away from TDC. In this case, the volume of the combustion chamber increases fast and causes the reduction in combustion temperature. As a result, it reduces thermal efficiency and thus reduces brake torque, brake power and BSFC as well. The lower combustion temperature generates, the lower NOx obtains. However, lower combustion temperature and higher time loss of incomplete combustion has increased opacity emission.

It is clear that the change of injection timing has the direct effects on engine performance and emission characteristics of a diesel DI engine. 

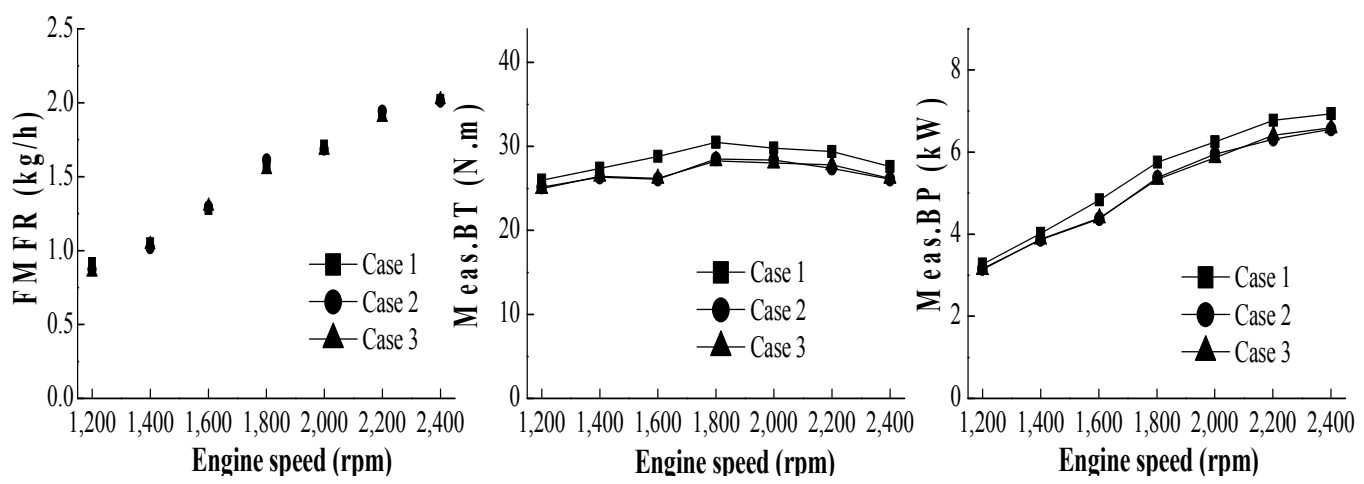

Fig. 6 Friction loss determination and fuel delivery check

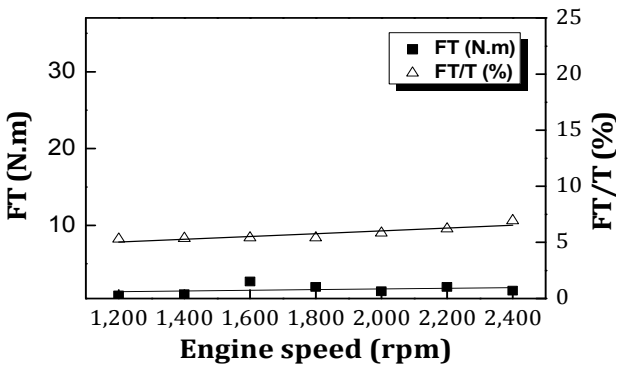

Fig. 7 Friction torque vs. speed
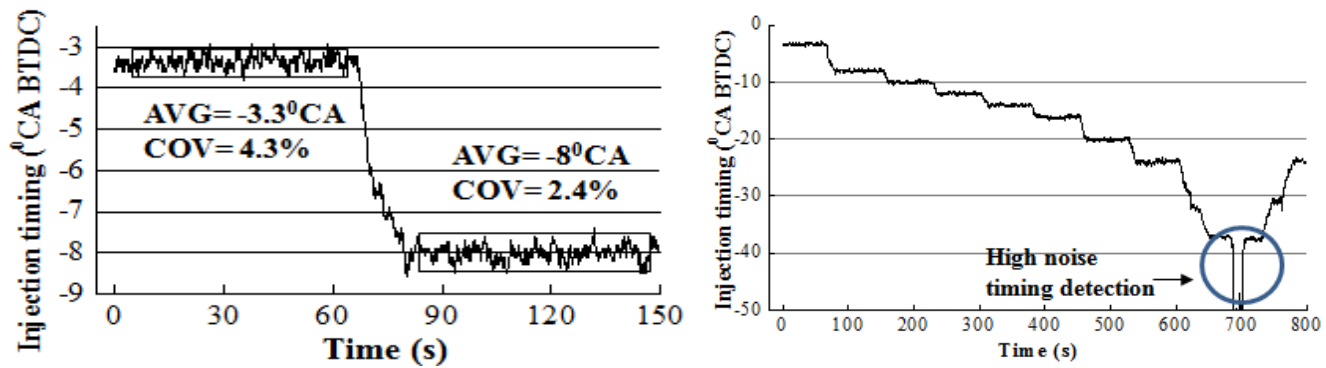

Fig. 8 Accuracy and stability of actual injection timing 


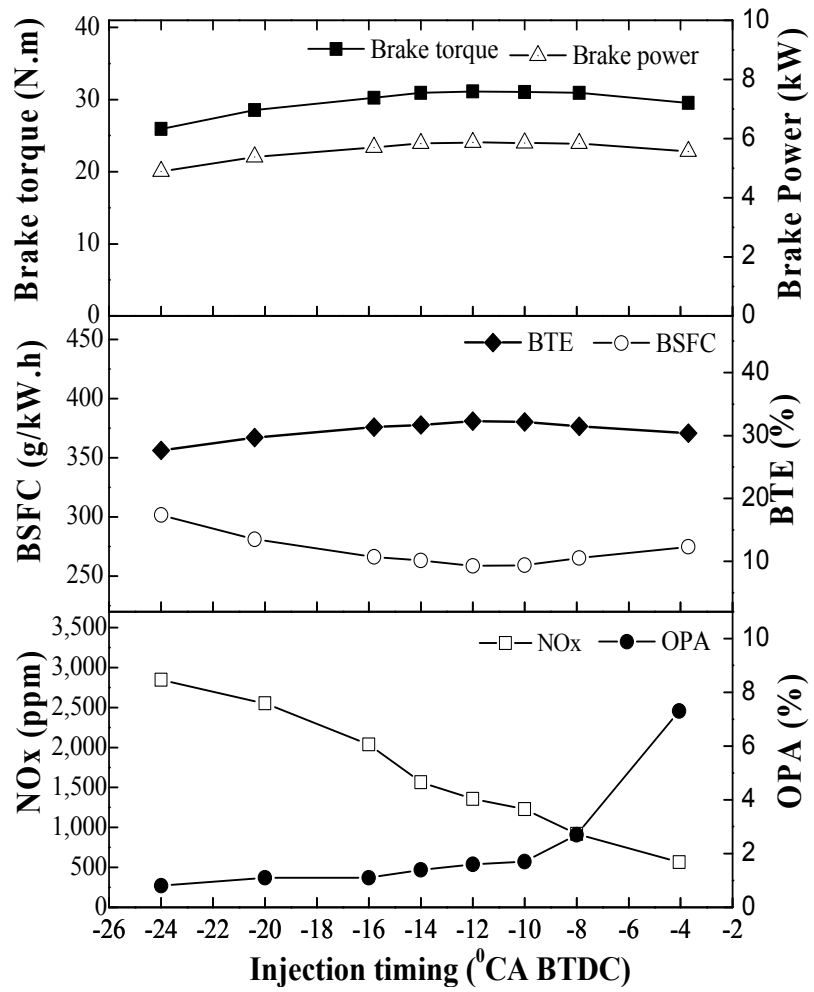

Fig. 9 Effect of injection timing on engine performance at constant load and engine speed

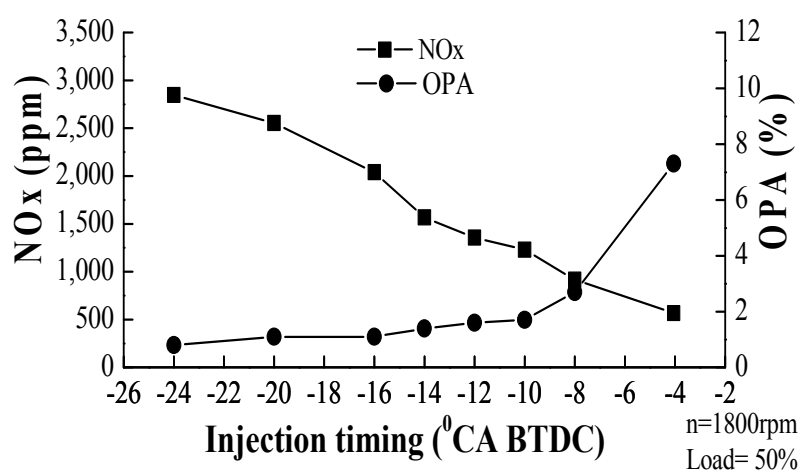

Fig. 10 Effect of injection timing on NOx and opacity at constant load and engine speed

\section{CONCLUSIONS AND FURTHER STUDIES}

A newly mechanical continuously variable injection timing system is properly designed for small diesel DI engines that could be operated with high stability and reliability. The preliminary results show that: (1) While operating with MCVIT system, the deviations of measured brake torque and power are only max. 0.4 N.m and max. $86 \mathrm{~W}$ respectively; (2) MCVIT 
system can support to change of injection timing of engine over a wide range from 0 to $400 \mathrm{CA}$ BTDC with the maximum deviation of $\pm 1.00 \mathrm{CA}$ for specific injection timing; (3) The change of injection timing could affect to engine performances. The brake torque and power are found injection timings at between 8 and $14^{\circ} \mathrm{CA}$ BTDC; (4) Injection timing is advanced, $\mathrm{NO}_{\mathrm{x}}$ increases, opacity decreases, and vice versa; (5) For development of agricultural engines that are made in Vietnam, the further effects of injection parameters on engine performance and emission characteristics are required to study.

Acknowledgment: Special thanks to Mr. Tran Dang Long and Mr. Chiem Tran Lam for their full support in doing the experiments in this work at Key-lab for internal combustion engines, Ho Chi Minh City University of Technology.

\section{Nghiên cứu hệ thống thay đổi liên tục thời điểm phun nhiên liệu dùng trong cải tiến động cơ Diesel nông nghiệp công suất nhỏ}

- Huỳnh Thanh Công

Phòng thí nghiệm Trọng điểm ĐHQG-HCM Động cơ đốt trong, htcong@hcmut.edu.vn

\section{TÓM TÁ́T}

Bài báo này trình bày một nghiên cứu phát triển hệ thống MCVIT cho phép thay đổi liên tục thời điểm phun nhiên liệu dùng trong nghiên cứu phát triển động cơ diesel nông nghiệp. Ứng dụng hệ thống này sẽ góp phần đánh giá ảnh hưởng của thời điểm phun nhiên liệu đến khả năng cải thiện đặc tính công suất và khí thải động cơ nhằm đáp ứng tiêu chuẩn khí thải hiện đại và thích hợp hơn trong việc sử dụng nhiên liệu sinh học trong tương lai. Hệ thống MCVIT được thiết kế, chế tạo có khả năng điều chỉnh trực tiếp thời điểm phun trong dãy rộng từ 0-40 độ trước điểm chết trên trong khi vẫn duy trì áp suất phun. Các thực nghiệm xác định đặc tính quan trọng của hệ thống như tổn hao co giới theo tốc độ, độ chính xác và độ tin cậy của kết quả đo. Kết quả cho thấy tổn hao mô-men lớn nhất của hệ thống nghiên cứu là khoảng 2,6 Nm trên toàn dãy tốc độ khảo sát và độ sai lệch tối đa của sự thay đổi góc phun là $\pm 1.0^{\circ} \mathrm{CA}$. Nghiên cứu thực nghiệm sơ bộ dựa trên động cơ diesel nông nghiệp Vikyno RV1252 cho thấy thời điểm phun nhiên liệu diesel có ảnh hưởng trực tiếp đến công suất và khí thải động co. Vì vậy, hệ thống MCVIT là một giải pháp hiệu quả và giá thấp trong các hoạt động $R \& D$ trong việc nghiên cứu phát triển dòng động cơ diesel sản xuất tại Việt Nam.

Từ khóa: Động cơ diesel phun trực tiếp, thời điểm phun, công suất, hệ thống MCVIT 


\section{REFERENCES}

[1] L. V. Hung, C. T. Lam, T. D.Long, H. T. Cong, N. A. Thi, D. V. Dung, A Preliminary Investigation of Performance Characteristics of Agricultural Diesel 12.5

HP Engine, Vietnam Mechanical Engineering Magazine, no 3, (2012).

[2] I. K.Reksowadojo, D. K. Dinh, N. Surjana, A. J. Kigour, T. P.Brodjoegoro, T. H.Soerawidjaja, and W. Arismunandar, Performance, Emissions of Pure Plant Oils (PPO) fuelled a Low Speed Indirect Injection Diesel Engine, in The 4th AUN/SEED-Net RC MeAe, (2012).

[3] G. Amba Prasad Rao, Syed Kaleemuddin, Development of variable timing fuel injection cam for effective abatement of diesel engine emissions, Applied Energy 88 2653-2662. (2011).

[4] S Hassan, Z A Zainal and M A Miskam, Effects of advanced injection timing on performance and emission of a supercharged dual-fuel diesel fueled by producer gas from downdraft gasifier, Journal of Scientific \& Industrial Research Vol.70, March 2011, 220-224, (2011).

[5] K. Mollenhauer and H. Tschoke, Handbook of Diesel Engines. Springer, (2010).

[6] J. B. Heywood, Internal Combustion Engine Fundamentals, McGraw-Hill International Editions. (1989).

[7] Chiem Tran Lam, Huynh Thanh Cong, Effect Of Injection Timing On Performance Characteristics Of Agricultural Diesel Di Engine Using Iso $8178 \mathrm{C} 1$ Test Cycle, Proceedings of the $6^{\text {th }}$ AUN/SEED-Net Regional Conference on New and renewable Energy, Bandung, Indonesia, Sep 2013 (ISBN 978-602-69269-1-9), 263273. (2013). 